\title{
PELATIHAN MEMBUAT APLIKASI ANDROID PEMULA
}

\author{
Deni Kuswoyo ${ }^{*}$ \\ ${ }^{1}$ Program Studi Teknologi Rekayasa Multimedia, Politeknik Negeri Media Kreatif, Indonesia \\ Deni.kuswoyo@polimedia.ac.id
}

\begin{abstract}
ABSTRAK
Abstrak: Perkembangan industri perangkat android pada tahun 2020 mengalami peningkatan malampai panjualan iOS Apple, yang mencari developer aplikasi android banyak dicari oleh industri kreatif. Banyak peserta yang kurang dalam keterampilan membuat aplikasi android. Diharapkan dengan pelatihan ini peserta yang mengikuti pelatihan mendapat gambaran dan pengetahuan tentang aplikasi android dan dapat mempersiapkan portofolio yang lebih baik untuk melamar pekerjaan. Metode pelatihan terdiri dari kegiatan presentasi, tanya jawab, simulasi media dan praktik membuat aplikasi secara langsung. Peserta mendapat softskill prinsip-prinsip dasar mendesain dan membuat code aplikasi , serta mampu dalam mengoperasikan software android studio.Tolak ukur keberhasilan dalam kegiatan ini kehadiran peserta mencapai angka lebih $80 \%$ dari pendaftar.
\end{abstract}

Kata Kunci: pelatihan, aplikasi, android.

Abstract: The development of the android device industry in 2020 has increased beyond Apple's iOS sales, which is looking for android developer applications that are sought after by the creative industry. Many participants lack the skills to create android applications. It is hoped that with this training, participants who take part in the training will get an overview and knowledge of android applications and can prepare a better portfolio for applying for jobs. The method consists of presentation activities, question and answer, media simulation and practice making applications directly. Participants gain soft skills in the basic principles of designing and coding applications, as well as being able to operate Android studio software. To measure success in this activity, participants reached more than $80 \%$ of the registrants.

Keywords: training, application, android.

\section{A. LATAR BELAKANG}

Penjualan perangkat android mencapai 1,6 miliar unit pada 2020, jumlah penjualan ini melampaui penjualan iOS Apple yang hanya terjual 284 juta unit (katadata,2016). Untuk membuat aplikasi bagi semua perangkat android, Android Studio menyediakan alat untuk pengujian, publikasi dan development terpadu yang menyertakan template untuk fitur aplikasi umum.

Para peserta yang telah mengikuti pelatihan telah dibekali kemampuan aplikasi android dalam kebutuhan aplikasi di pasaran dan mata pelajaran di provinsi Riau (nasution, nurliana 2018). Kegiatan yang dilakukan dengan membuat modul pelatihan yang terdiri dari Bagan I Projek Latihan, Bagan II Konsep Dasar, Bagan III Project Latihan Game Dasar (Bola Tangkis), Bagan IV Project Latihan Game Dasar (Hangman) dan Bab V Upload aplikasi ke Playstore.

Berdasarkan hasil kuisioner yang dibagikan, mendapatkan hasil bahwa pemahaman peserta mengenai pembuatan aplikasi android meningkat setelah kegiatan (nasution, 
akmal 2019). Kegiatan yang dilakukan yaitu penjelasan dan praktik pembuatan aplikasi android yang terdiri dari pengenalan, mendesain tampilan dan membuat code aplikasi.

Rumah siap kerja beralamat di Jl. Wijaya I No. 26, Jakarta Selatan, DKI Jakarta 12170 merupakan tempat bagi para anak muda untuk mendapatkan bimbingan karir, informasi lowongan kerja, pelatihan professional dan Pendidikan bagi anak muda. Setelah melakukan koordinasi dengan penyelenggara penulis diizinkan mengadakan kegiatan pelatihan membuat aplikasi android pemula.

Dengan pelatihan ini diharapkan dapat meningkatkan pengetahuan dan keterampilan para peserta yang mengikuti kegiatan pelatihan dalam membuat aplikasi android menggunakan Android Studio dan kedepannya dapat memperoleh pekerjaan dalam bidang teknologi aplikasi android.

\section{B. METODE PELAKSANAAN}

Kegiatan pelatihan membuat aplikasi android pemula menggunakan metode pelatihan yang terdiri dari kegiatan presentasi, tanya jawab, simulasi media dan praktik membuat aplikasi secara langsung.

Rumah siap kerja digagas oleh Sandiaga Uno sebagai salah satu program kerja pada saat kampanya pemilihan Presiden RI tahun 2019. Berdiri pada 16 Maret 2019, beralamat di Jl. Wijaya I No. 26, Jakarta Selatan, DKI Jakarta 12170. Sejak awal berdiri telah mengadakan lebih dari 200 pelatihan profesional. Sejak akhir tahun 2019, Rumah Siap Kerja telah bebas dari afiliasi politik dan kini dipimpin oleh Reostiadi Tsamanov. Rumah Siap Kerja merupakan tempat bagi para anak muda untuk mendapatkan bimbingan karir, mencari informasi lowongan pekerjaan, pelatihan professional dan Pendidikan yang didukung dalam beragam fasilitas bagi anak muda. Pelatihan ini diminati sebanyak 70 peserta yang mendaftar dalam kegiatan. 
Pelaksanaan kegiatan pelatihan memiliki langkah kerja sebagai berikut :

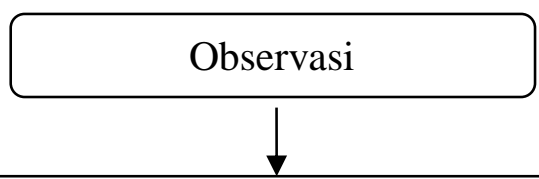

Berdasarkan observasi di Rumah Siap Kerja, pelatihan Aplikasi Android ini melibatkan peserta yang belum dan sudah mengetahui software android studio dan penerapan aplikasi android yang akan digunakan dalam pelatihan, materi/modul sebagai bekal dalam mengajar dan panduan peserta untuk memahami lebih lanjut, jadwal pelatihan di sesuaikan dengan agenda Rumah Siap Kerja.

Pelaksanaan Pelatihan: - Pelatihan ini mencakup dasar Aplikasi Android, melakukan desain aplikasi dan code aplikasi android. - Fasilitas seperti laptop, TV Monitor dan Sound disediakan sesuai kebutuhan bisa dari pihak peserta maupun dari kegiatan pelaksana

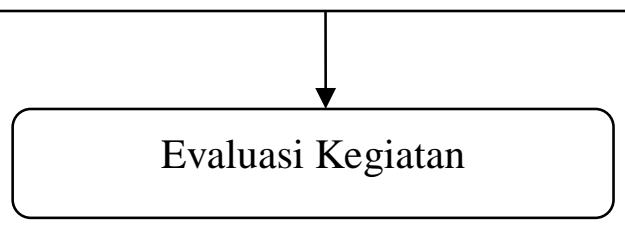

1. Observasi langsung.

a. Survei tempat pelaksanaan kegiatan.

b. Kegiatan pengabdian masyarakat membuat aplikasi android pemula pengabdi sudah mengetahui tentang teknologi dan penerapan aplikasi yang akan digunakan dalam pelatihan.

c. Pembuatan bahan materi/modul sebagai bekal dalam mengajar dan panduan peserta untuk memahami lebih lanjut tentang materi pelatihan.

d. Jadwal pelatihan yang tentunya disesuaikan dengan agenda Rumah Siap Kerja yang terlebih dahulu dikoordinasikan dengan pihak panitia.

e. Koordinasi dalam penyediaan fasilitas pelatihan seperti laptop, Monitor TV dan Sound.

2. Pelatihan.

a. Pelatihan ini mencakup dasar-dasar desain aplikasi android dan memprogram aplikasi android. Peserta pelatihan akan mengikuti semua kegiatan pelatihan. 
b. Target kuota kegiatan pelatihan ini adalah 70 peserta pelatihan yang merupakan jumlah kapasitas dari ruangan akan dilaksanakan pada Tanggal 12 Desember 2019 dengan tanggal yang telah disepakati dengan pihak Rumah Siap Kerja.

c. Fasilitas seperti laptop, Monitor TV, dan Sound disediakan sesuai kebutuhan dari pihak pelaksana.

d. Pelatihan diselenggarakan dengan perpaduan antara teori dan praktek dengan perbandingan $30: 70$. Sejumlah penelitian membuktikan praktek langsung dapat meningkatkan pemahaman dalam belajar.

3. Evaluasi.

Setelah pelatihan berakhir, tentunya perlu adanya evaluasi yang dilakukan untuk melihat sejauh mana perkembangan hasil yang didapatkan dari pelatihan apakah telah berjalan dengan baik atau belum sekaligus evaluasi kekurangan dari pelaksanaan. Selama kegiatan juga dilakukan pengamatan apakah tujuan dan target dari pelaksanaan pelatihan ini sudah tercapai untuk sekaligus membahas tentang kendala-kendala yang mungkin ditemui dalam pelaksanaan.

\section{HASIL DAN PEMBAHASAN}

Kegiatan pelatihan membuat aplikasi android pemula menggunakan metode pelatihan yang terdiri dari kegiatan presentasi, tanya jawab, simulasi media dan praktik membuat aplikasi secara langsung.

1. Kegiatan Observasi

1. Survei Lokasi Mitra

Pada tanggal 20 November 2019 melakukan survei ke lokasi Rumah Siap Kerja untuk melihat tempat dan bertemu panitia penyelenggara.

2. Permohonan Izin Pelatihan

Pada tanggal 23 November 2019 setelah mendapat surat tugas dari LPPM Politeknik Negeri Media Kreatif untuk meminta izin untuk melakukan kegiatan pengabdian masyarakat di Rumah Siap Kerja dalam bentuk pelatihan Membuat Aplikasi Android Pemula.

3. Persiapan Pelatihan

Setelah mendapatkan izin dari pihak mitra, kemudian kami mulai menyusun modul materi pelatihan aplikasi android yang akan dibagikan kepada peserta pelatihan. Untuk jumlah peserta yang mengikuti pelatihan ini sebanyak 70 peserta yang dibuka oleh Rumah Siap Kerja.

2. Kegiatan Pelatihan

1. Pemberian materi pembuatan aplikasi android pemula. 
Materi yang kami berikan adalah materi tentang dasar-dasar mendesain aplikasi android dan memprogram aplikasi android yang terdiri dari:

a) Langkah-langkah pembuatan desain aplikasi android

b) Mebuat program aplikasi android.

Kegiatan pengabdian masyarakat ini dilaksanakan di Rumah Siap Kerja Jakarta Selatan yang dikuti oleh peserta yang telah mendaftar pelatihan ,kegiatan pelatihan berjalan dengan baik dan lancar, antusias dari peserta yang hadir sangat luar biasa. Terbukti dalam waktu yang relative singkat peserta dapat menggunakan software android studio dan membuat aplikasi android sederhana pada laptop masing-masing.

Pelatihan dilaksanakan pada

Hari : Kamis, 12 Desember 2019

Waktu $\quad: 14.00-17.00 \mathrm{WIB}$

Tempat : Rumah Siap Kerja

Table 4.1. Jadwal Pelaksanaan Kegiatan Pelatihan

\begin{tabular}{|c|c|c|c|c|}
\hline NO & $\begin{array}{c}\text { HARI/ } \\
\text { TANGGAL }\end{array}$ & WAKTU & KEGIATAN & KETERANGAN \\
\hline \multirow{6}{*}{1} & \multirow{6}{*}{$\begin{array}{c}\text { Kamis, } \\
12 \text { Desember } 2019\end{array}$} & $\begin{array}{c}14.00- \\
14.15 \\
\end{array}$ & Pembukaan & Panitia \\
\hline & & $\begin{array}{c}14.15- \\
14.30 \\
\end{array}$ & Pengenalan Aplikasi & Tim Pelaksana \\
\hline & & $\begin{array}{l}14.30- \\
14.45 \\
\end{array}$ & Install Aplikasi & Tim Pelaksana \\
\hline & & $\begin{array}{l}14.45- \\
15.00\end{array}$ & $\begin{array}{l}\text { Setting Handphone dan } \\
\text { aplikasi }\end{array}$ & Tim Pelaksana \\
\hline & & $\begin{array}{l}15.00- \\
16.30 \\
\end{array}$ & $\begin{array}{c}\text { Praktek penggunaan } \\
\text { aplikasi }\end{array}$ & Peserta \\
\hline & & $\begin{array}{c}16.30- \\
17.00 \\
\end{array}$ & Penutupan & Panitia \\
\hline
\end{tabular}

3. Evaluasi Kegiatan

\section{Sasaran}

Para peserta mampu menggunakan software android studio untuk mendesain aplikasi android.

Para peserta mampu menggunakan software android studio untuk memprogram aplikasi android.

2. Indicator Keberhasilan

Para peserta mampu menggunakan software android studio dalam membuat aplikasi kegiatan belajar mengajar.

Para warga mampu menggunakan sofrware android studio untuk mendesain dan memprogram aplikasi android.

4. Kendala saat Kegiatan

1. Beberapa peserta yang mengalami kendala saat instalasi software Android Studio karena membutuhkan spesifikasi yang cukup tinggi.

2. Beberapa peserta kesulitan mengikuti belajar code aplikasi android karena belum pernah membuat coding aplikasi. 


\section{SIMPULAN DAN SARAN}

Kegiatan pelatihan membuat aplikasi android pemula, peserta mendapat gambaran dan pengetahuan tentang membuat aplikasi android. Setelah pelaksanaan peserta mendapat softskill prinsip-prinsip dasar mendesain dan membuat code aplikasi, serta mampu dalam mengoperasikan software android studio. Berdasarkan tanggapan, respon, dan partisipasi para peserta disimpulkan bahwa peserta cukup dengan adanya pelatihan ini karena mereka mampu melakukan instalasi dan penggunaan software android studio. Tolak ukur keberhasilan dalam kegiatan ini kehadiran peserta mencapai angka lebih $80 \%$ dari pendaftar.

Manfaat pelatihan ini telah langsung dapat dirasakan oleh peserta setelah Pratik dalam membuat aplikasi android. Setelah pelatihan ini selanjutnya dapat diupayakan keberlanjutan demi meningkatkan keahlian peserta dalam aplikasi android.

\section{UCAPAN TERIMA KASIH}

Penulis mengucapkan terima kasih kepada Lembaga Pengabdian Pada Masyarakat (LPPM) Politeknik Negeri Media Kreatif yang telah mendukung kegiatan pelatihan ini sehingga terlaksana dengan baik.

Penulis mengucapkan terima kasih kepada Rumah Siap Kerja yang telah bersedia memberikan kesempatan untuk melaksanakan pengabdian masyarakat.

\section{DAFTAR RUJUKAN}

Android Developer (2016) android developer fundamentals course Desember 2016 (https://developer.android.com/courses/fundamentals-training/overview-v2)

Arifianto, Teguh. (2011). Membuat Interface Aplikasi Android Lebih Keren dengan LWUIT. Yogyakarta: Andi Publisher

Hermawan S, Stephanus. 2011."Mudah Membuat Aplikasi Android".Yogyakarta : Andi Offset. Nasution, Akmal. (2019). Pelatihan Membuat Aplikasi Android dengan Android Studio pada SMP Negeri 1 Tinggi Raja. Jurdimas (Jurnal Pengabdian Kepada Masyarakat) Royal, Vol. 2 No.1, Jan 2019

Nasution, Nurliana. (2018). Pelatihan Pembuatan Aplikasi Android Sebagai Bekal Technopreneurship untuk Peningkatan Daya Ekonomi Mandiri Alumni SMK di Pekanbaru. Jurnal Pengabdian Masyarakat, Vol.2 No.3, 2018 